\title{
Antagonistic lactic acid bacteria isolated from goat milk and identification of a novel nisin variant Lactococcus lactis
}

\author{
Luana Martins Perin ${ }^{\dagger}$ and Luís Augusto Nero ${ }^{*+}$
}

\begin{abstract}
Background: The raw goat milk microbiota is considered a good source of novel bacteriocinogenic lactic acid bacteria (LAB) strains that can be exploited as an alternative for use as biopreservatives in foods. The constant demand for such alternative tools justifies studies that investigate the antimicrobial potential of such strains.

Results: The obtained data identified a predominance of Lactococcus and Enterococcus strains in raw goat milk microbiota with antimicrobial activity against Listeria monocytogenes ATCC 7644. Enzymatic assays confirmed the bacteriocinogenic nature of the antimicrobial substances produced by the isolated strains, and PCR reactions detected a variety of bacteriocin-related genes in their genomes. Rep-PCR identified broad genetic variability among the Enterococcus isolates, and close relations between the Lactococcus strains. The sequencing of PCR products from nis-positive Lactococcus allowed the identification of a predicted nisin variant not previously described and possessing a wide inhibitory spectrum.

Conclusions: Raw goat milk was confirmed as a good source of novel bacteriocinogenic LAB strains, having identified Lactococcus isolates possessing variations in their genomes that suggest the production of a nisin variant not yet described and with potential for use as biopreservatives in food due to its broad spectrum of action.
\end{abstract}

\section{Background}

Goat milk is the second variety of milk most produced in the world [1]. Their production is increasing mainly because it could be an alternative to substitute the consumption of cow milk, due to evidences that it does not induce allergies, presents high digestibility, and also possess high nutritional quality [2]. As cow milk, goat milk has a very rich and complex autochthonous microbiota, and its detailed knowledge is essential for a future use of this matrix for the production of fermented products $[3,4]$. The main responsible for the natural fermentation of these products are microorganisms from the Lactic Acid Bacteria (LAB) group, that are widely studied due to their potential use as adjuvants and biopreservatives in foods [3,5-8]. Many studies already demonstrated that BAL has considerable inhibitory activity against pathogenic and

\footnotetext{
* Correspondence: nero@ufv.br

${ }^{\dagger}$ Equal contributors

Departamento de Veterinária, Universidade Federal de Viçosa, Viçosa, Minas Gerais 36570 000, Brazil
}

spoilage microorganisms in foods [7-12], mainly by the production of bacteriocins [13,14].

Bacteriocins are small peptides that present antimicrobial activity and are of particular interest to food industries, representing natural alternatives to improve the safety and quality of foods $[13,15]$. Considering these characteristics, new bacteriocinogenic LAB strains and their bacteriocins are continuously searched, however only nisin and pediocin are the bacteriocins allowed to be applied in food, including cheeses $[15,16]$. Nisin is a lantibiotic produced by some Lactococcus lactis strains and up to now five nisin variants are already known: nisin A (the first to be discovered), Z, Q, U and F [17-19]. The differences between these variants are based on the changes in the amino acid chain, what could interfere in their antimicrobial activity.

The main sources of novel LAB strains capable of producing bacteriocins are food systems, mainly ones that are naturally contaminated with a diversity of microorganisms, such as animal origin products $[9,20,21]$. The production characteristics of meat and dairy products 
facilitate contamination by distinct microbial groups, determining a rich autochthonous microbiota in such food products. In this context, the autochthonous microbiota of raw goat milk is particularly interesting due to its diversity and the presence of several bacteriocinogenic LAB strains, as observed in previous studies [4,5,22,23]. Once isolated from a food sample, the antimicrobial activity of bacterocinogenic LAB strains must be properly characterized [24]. Relevant information that must be investigated includes possible bacteriocins the strains are able to produce, which can be assessed by the identification of specific genes related to known bacteriocins, followed by sequencing to identify variants $[25,26]$. Additionally, it is important to verify the inhibitory spectrum of the bacteriocins produced by newly isolated LAB strains. Such data can justify further studies with purified bacteriocins, in order to check a diversity of characteristics that allow their use in the food industry as biopreservatives.

The present study aimed to characterize the diversity of the main LAB groups that compose the autochthonous microbiota of raw goat milk and their bacteriocinogenic potential, in order to identify novel strains capable of producing known bacteriocin variants with potential application as biopreservatives.

\section{Methods}

\section{Samples and microbiological analysis}

Raw goat milk samples were collected from 11 goat farms (two samples per farm) located in Viçosa, Minas Gerais state, Brazil, and subjected to ten-fold dilution using $0.85 \% \mathrm{NaCl}(\mathrm{w} / \mathrm{v})$. Selected dilutions were pour plated in duplicate and in distinct culture media: M17 (Oxoid Ltd., Basingstoke, England, incubated at $35^{\circ} \mathrm{C}$ for $48 \mathrm{~h}$, and at $42^{\circ} \mathrm{C}$ for $48 \mathrm{~h}$ ), de Man, Rogosa and Sharpe (MRS) (Oxoid, incubated at $30^{\circ} \mathrm{C}$ for $48 \mathrm{~h}$, under anaerobic conditions using GasPak EZ ${ }^{\mathrm{mm}}$ Gas Generating Container Systems, BD - Becton, Dickinson and Co., Franklin Lakes, NJ, USA), MRS at pH 5.5 (Oxoid, incubated at $35^{\circ} \mathrm{C}$ for $48 \mathrm{~h}$, under anaerobic conditions using GasPak, BD), and Kanamycin Aesculin Azide (Oxoid, incubated at $35^{\circ} \mathrm{C}$ for $48 \mathrm{~h}$ ). After incubation, colonies were enumerated and the results expressed as log colonyforming units per $\mathrm{mL}(\log \mathrm{cfu} / \mathrm{mL})$. From each culture media and sample, representative colonies were selected (about 10\% of the observed count) and subjected to Gram staining and checked for catalase production. LAB characteristic colonies were subjected to addition microbiological analysis as described in the following sections.

\section{Antimicrobial activity and bacteriocin production}

Isolates identified as LAB (Gram positive and catalase negative) were subjected to the spot-on-the-lawn method to identify their antimicrobial activity against Listeria monocytogenes ATCC 7644, according to CB Lewus, A Kaiser and TJ Montville [27]. Briefly, LAB isolates were cultured in MRS broth (Oxoid) at $35^{\circ} \mathrm{C}$ for $24 \mathrm{~h}$, after which $1 \mu \mathrm{L}$ aliquots were spotted on the surface of MRS agar (Oxoid) and incubated at $25^{\circ} \mathrm{C}$ for $24 \mathrm{~h}$ under anaerobic conditions (GasPak, BD); then, brain heart infusion (BHI, Oxoid) broth was added to bacteriological agar at $0.8 \%(\mathrm{w} / \mathrm{v})$ and L. monocytogenes ATCC 7644 at $10^{5} \mathrm{cfu} / \mathrm{mL}$ was overlaid and incubated at $35^{\circ} \mathrm{C}$ for $24 \mathrm{~h}$. The presence of inhibition halos was recorded as the antimicrobial activity of the tested isolate.

Isolates that presented antimicrobial activity were subjected to the spot-on-the-lawn protocol $[27,28]$ to identify the bacteriocinogenic nature of their antimicrobial substances. For this, after the first incubation of the tested isolates in MRS plates, $2 \mathrm{~mm}$ diameter wells were cut adjacent to the colonies and enzyme solutions at $20 \mathrm{mg} / \mathrm{mL}$ were added: $\alpha$-chimotrypsin, proteinase $\mathrm{K}$, TPCK trypsin, $\alpha$-amylase, papain, Streptomyces griseus protease, Aspergillus niger lipase, and lysozyme (all from Sigma-Aldrich, Inc., St. Louis, MO, USA). Half-moon halos associated with proteases were indicative of the bacteriocinogenic nature of the antimicrobial substances produced by the tested isolates.

\section{Molecular identification and rep-PCR fingerprinting of bacteriocinogenic isolates}

Bacteriocinogenic isolates were cultured in MRS broth (Oxoid) at $35^{\circ} \mathrm{C}$ for $12 \mathrm{~h}$, and the obtained cultures were subjected to DNA extraction using the Genomic Wizard DNA Purification Kit (Promega Corp., Madison, WI, USA).

Identification of these isolates was done by sequencing their 16S rRNA genes using the primers P1V1 and P4V3 (Table 1). Isolates identified as Enterococcus spp. were identified at the species level by sequencing the pheS (phenylalanyl-tRNA synthase $\alpha$-subunit) gene using the primers pheS-21 and pheS-22 (Table 1). PCR reactions consisted of $25 \mu \mathrm{L}$ of Go Taq Green Master Mix 2x (Promega), $10 \mathrm{pMol}$ of each pair of primers, $2 \mu \mathrm{L}$ of DNA (50 ng/ $\mu \mathrm{L}$ ) and ultra pure PCR water (Promega) to a final volume of $50 \mu \mathrm{L}$. PCR conditions for $16 \mathrm{~S}$ rRNA were as described by $\mathrm{N}$ Klijn, AH Weerkamp and WM de Vos [29], and for pheS as detailed by SM Naser, FL Thompson, B Hoste, D Gevers, P Dawyndt, M Vancanneyt and J Swings [30], using the annealing temperatures described in Table 1 . The PCR products (Table 1) were double-strand sequenced by Macrogen Inc. (Seoul, Korea), and the identification was given only for sequences with $100 \%$ of similarity when compared to the database of the National Center for Biotechnology Information (NCBI, http://www.ncbi.nlm.nih.gov/genbank) using the software Basic Alignment Search Tool (BLAST, p://www.ncbi.nlm. nih.gov/blast.cgi). 
Table 1 Primers sequences, annealing temperatures, and expected fragment sizes of PCR reactions targeting specific genes for identification and bacteriocins encoding genes

\begin{tabular}{|c|c|c|c|c|}
\hline Target & Primers sequences (5'-sequence- 3 ') & Fragment size (bp) & Annealing & Reference \\
\hline \multirow[t]{2}{*}{$16 \mathrm{~S}$ rRNA } & GCGGCGTGCCTAATACATGC & 700 & $42^{\circ} \mathrm{C}$ & {$[29]$} \\
\hline & ATCTACGCATTTCACCGCTAC & & & \\
\hline \multirow[t]{2}{*}{ phes } & CAYCCNGCHCGYGAYATGC & 470 & $46^{\circ} \mathrm{C}$ & {$[30]$} \\
\hline & CCWARVCCRAARGCAAARCC & & & \\
\hline \multirow[t]{2}{*}{$\operatorname{lan} B$} & TATGATCGAGAARYAKAWAGATATGG & $400-500$ & $40^{\circ} \mathrm{C}$ & {$[17,19]$} \\
\hline & TTATTAIRCAIATGIAYDAWACT & & & \\
\hline \multirow[t]{2}{*}{$\operatorname{lanC}$} & TAATTTAGGATWISYIMAYGG & $200-300$ & $40^{\circ} \mathrm{C}$ & {$[17,19]$} \\
\hline & ACCWGKIIIICCRTRRCACCA & & & \\
\hline \multirow[t]{2}{*}{ lanM } & ATGCWAGWYWTGCWCATGG & $200-300$ & $40^{\circ} \mathrm{C}$ & {$[17,19]$} \\
\hline & CCTAATGAACCRTRRYAYCA & & & \\
\hline \multirow[t]{2}{*}{ nis } & GGATAGTATCCATGTCTG & 250 & $55^{\circ} \mathrm{C}$ & {$[31]$} \\
\hline & CAATGATTTCGTTCGAAG & & & \\
\hline \multirow[t]{2}{*}{ entA } & CATCATCCATAACTATATTTG & 126 & $56^{\circ} \mathrm{C}$ & {$[32]$} \\
\hline & AAATATTATGGAAATGGAGTGTAT & & & \\
\hline \multirow[t]{2}{*}{ entB } & GAAAATGATCACAGAATGCCTA & 162 & $58^{\circ} \mathrm{C}$ & {$[32]$} \\
\hline & GTTGCATTTAGAGTATACATTTG & & & \\
\hline \multirow[t]{2}{*}{ entP } & TATGGTAATGGTGTTTATTGTAAT & 120 & $58^{\circ} \mathrm{C}$ & {$[32]$} \\
\hline & ATGTCCCATACCTGCCAAAC & & & \\
\hline \multirow[t]{2}{*}{ entL50AB } & STGGGAGCAATCGCAAAATTAG & 98 & $56^{\circ} \mathrm{C}$ & {$[32]$} \\
\hline & ATTGCCCATCCTTCTCCAAT & & & \\
\hline \multirow[t]{2}{*}{ entAS48 } & GAGGAGTITCATGATITAAAGA & 340 & $56^{\circ} \mathrm{C}$ & {$[32]$} \\
\hline & CATATTGTTAAATTACCAAGCAA & & & \\
\hline
\end{tabular}

Rep-PCR was performed according the protocol described by B Dal Bello, K Rantsiou, A Bellio, G Zeppa, R Ambrosoli, $\mathrm{T}$ Civera and $\mathrm{L}$ Cocolin [9] using a single primer (GTG) 5 (5'-GTGGTGGTGGTGGTG-3'). PCR reactions contained $12.5 \mu \mathrm{L}$ of Go Taq Green Master Mix 2x (Promega), $50 \mathrm{pMol}$ of the primer, $2 \mu \mathrm{L}$ of DNA (50 ng/ $\mu \mathrm{L}$ ) and ultra pure PCR water (Promega) to a final volume of $25 \mu \mathrm{L}$. PCR conditions were: 1) $5 \mathrm{~min}$ at $95^{\circ} \mathrm{C}$, (2) 30 cycles of $30 \mathrm{~s}$ at $95^{\circ} \mathrm{C} ; 30 \mathrm{~s}$ at $40^{\circ} \mathrm{C}$ and $8 \mathrm{~min}$ at $65^{\circ} \mathrm{C}$, and (3) final extension of $16 \mathrm{~min}$ at $65^{\circ} \mathrm{C}$. PCR products were electrophoresed in $2 \%(\mathrm{w} / \mathrm{v})$ agarose gels for $6 \mathrm{~h}$ at a constant voltage of $75 \mathrm{~V}$, in $0.5 \times$ Tris/Borate/ EDTA buffer (TBE). Gels were stained using GelRed (Biotium Inc., Hayward, CA, USA), and recorded using a transilluminator LPIX (Loccus Biotecnologia, São Paulo, SP, Brazil). Fingerprints were analysed using BioNumerics 4.6 (Applied Maths, Kortrijk, Belgium): The similarities among profiles were calculated using the Pearson correlation. Dendograms were constructed using the Unweighted Pair Group Method with Arithmetic Mean (UPGMA).

\section{Bacteriocin encoding genes}

Bacteriocinogenic isolates were subjected to PCR to detect genes related to the expression of lantibiotics (lanB, lan $\mathrm{C}$, and lanM), nisin (nis), and enterocins (A, P, B, L50A, L50B, and AS-48) using the primers presented in Table 1. PCR reactions consisted of $12.5 \mu \mathrm{L}$ of Go Taq Green Master Mix 2x (Promega), 100 pMol of lantibiotics primers, or $60 \mathrm{pMol}$ of nisin primers, or $10 \mathrm{pMol}$ of enterocins primers, $1 \mu \mathrm{L}$ of DNA (200 ng/ $\mu \mathrm{L})$, and ultra pure PCR water (Promega) to a final volume of $25 \mu \mathrm{L}$. All PCR reactions were conducted according the following conditions: 1) $95^{\circ} \mathrm{C}$ for $\left.5 \mathrm{~min}, 2\right) 30$ cycles at $95^{\circ} \mathrm{C}$ for $1 \mathrm{~min}$, annealing temperature (Table 1) for $1 \mathrm{~min}$, and $72^{\circ} \mathrm{C}$ for $1 \mathrm{~min}$, and 3) final extension at $72^{\circ} \mathrm{C}$ for $10 \mathrm{~min}$. The PCR products were electrophoresed in $1 \%$ $(\mathrm{w} / \mathrm{v})$ agarose gels in $0.5 \times \mathrm{TBE}$, and stained in a GelRed bath (Biotium). Fragments with the specific expected sizes (Table 1) were recorded as positive results for each bacteriocin-encoding gene for each isolate. Positive results were confirmed by repeating the PCR reactions.

Nisin gene sequencing and inhibitory spectrum of nisin positive isolates

PCR products of nis-positive isolates were sequenced by Macrogen Inc. The obtained results were analysed using the software Sequencher ${ }^{\mathrm{TM}}$ 4.1.4 (Technology Drive, Ann Arbor, MI, USA) in order to identify similarities between 
the translated amino-acid sequences and a nisin $\mathrm{A}, \mathrm{Z}, \mathrm{Q}$, $\mathrm{F}$ or $\mathrm{U}$ sequences previously deposited in GenBank.

In addition, nisin-positive isolates were subjected to the spot-on-the-lawn protocol, as described previously [27], to identify their inhibitory activity against 22 target strains: 4 LAB, 4 Listeria spp., 2 Pseudomonas spp., 4 Salmonella spp., 6 Staphylococcus spp. and 2 E. coli. The diameters of the inhibition halos were measured to characterize the antimicrobial activities of the tested isolates.

\section{Results and discussion}

\section{LAB counts of raw goat milk}

The obtained mean counts for LAB of goat milk samples obtained by distinct culture media considered in the present study are presented in Table 2 . The mean counts ranged from 3.07 to $3.89 \log \mathrm{cfu} / \mathrm{mL}$, and a total of 682 colonies was selected from the plated culture media, among which 423 were characterized as possessing typical LAB characteristics (Table 2). The majority of isolates from the LAB collection was characterized as cocci (377), a group described as the predominant component of raw milk microbiota [21,33]. The obtained results also highlighted the absence of adequate selectivity in the employed culture media, even for LAB (Table 2), necessitating further phenotypic analysis for proper characterization of the isolates [34]. The autochthonous microbiota of the goat milk could have originated mainly from utensils and environmental conditions, being highly influenced by the hygienic procedures of milking [35-37]. The method of storage also has a direct impact on the microbiota of raw milk, high temperatures being determinant for the predominance of lactococci [33].

\section{Antimicrobial activity and bacteriocin production}

From the LAB collection obtained from raw goat milk, 57 isolates presented antimicrobial activity against $L$. monocytogenes ATCC 7644 (Table 2). This foodborne pathogen was selected as a target because previous studies have demonstrated its susceptibility to the antimicrobial substances produced by LAB; it is usually adopted as an indicator of such activity [11,22,25,38,39].

The bacteriocinogenic activity was confirmed by the enzymatic assays in 54 of the 57 antagonistic isolates (Table 2). These isolates produced antimicrobial substances that were degraded by distinct enzymes solutions, mainly by proteinase $\mathrm{K}$ and Streptomyces griseus protease. The sensitivity to proteases indicated the proteinaceous nature of the produced substances, typical for bacteriocins $[13,40]$. In addition, the observed results indicated that the bactericions produced by the tested isolates would be degraded by pancreatic enzymes and they would not interfere with the intestinal microbiota of the consumer [41].

It was also observed that some isolates produced antimicrobial substances with sensitivities to $\alpha$-amylase (7) and lypase (28), suggesting the presence of carbohydrates and lipids in their structures $[42,43]$. These substances can interfere with bacteriocins stability, demanding further studies to verify their appropriateness as biopreservatives in foods [44].

Table 2 Mean counts and numbers of obtained isolates from distinct culture media used to enumerate presumptive lactic acid bacteria (LAB) groups from raw goat milk samples, and their typical LAB characteristics, antimicrobial activity, and sensitivity to eight distinct enzymatic solutions

\begin{tabular}{|c|c|c|c|c|c|c|c|}
\hline \multirow[t]{2}{*}{ Results } & \multirow[t]{2}{*}{ Group } & \multicolumn{5}{|c|}{ Culture media (incubation condition) $^{a}$} & \multirow[t]{2}{*}{ Total } \\
\hline & & $\mathrm{M} 17\left(35^{\circ} \mathrm{C}\right)$ & MRS (pH 5.5) & KAA & $\mathrm{M} 17\left(42^{\circ} \mathrm{C}\right)$ & MRS & \\
\hline Mean count (log $\mathrm{cfu} / \mathrm{mL})$ & & 3.89 & 3.47 & 3.07 & 3.65 & 3.61 & - \\
\hline Obtained isolates (n) & - & 134 & 138 & 142 & 128 & 140 & 682 \\
\hline \multirow[t]{2}{*}{ Typical LAB } & Gram positive cocci, catalase negative & 57 & 79 & 108 & 46 & 87 & 377 \\
\hline & Gram positive bacilli, catalase negative & 7 & 18 & 4 & 5 & 12 & 46 \\
\hline Antimicrobial activity ${ }^{\mathrm{b}}$ & - & 13 & 4 & 23 & 7 & 10 & 57 \\
\hline \multirow[t]{8}{*}{ Enzymatic sensitivity ${ }^{b}$} & a-chimotrypsin & 9 & 2 & 13 & 7 & 6 & 37 \\
\hline & Proteinase $\mathrm{K}$ & 11 & 1 & 18 & 6 & 10 & 46 \\
\hline & TPCK trypsin & 10 & 3 & 10 & 5 & 10 & 38 \\
\hline & a-amylase & 3 & 0 & 1 & 0 & 3 & 7 \\
\hline & Papain & 4 & 3 & 8 & 3 & 6 & 24 \\
\hline & Streptomyces griseus protease & 13 & 4 & 18 & 4 & 10 & 49 \\
\hline & Aspergillus niger lipase & 9 & 2 & 6 & 4 & 7 & 28 \\
\hline & lysozyme & 1 & 0 & 1 & 0 & 0 & 2 \\
\hline
\end{tabular}

aMRS: de Man, Rogosa and Sharpe; KAA: Kanamycin Aesculin Azide.

${ }^{\mathrm{b}}$ Identified by spot-on-the-lawn method [27] using Listeria monocytogenes ATCC 7644 as target. 


\section{Molecular identification and rep-PCR fingerprinting of bacteriocinogenic isolates}

All 57 isolates that presented antimicrobial activity against $L$. monocytogenes ATCC 7644, whether they produced antimicrobial substances sensitive to enzymes or not (Table 2), was subjected to molecular identification and rep-PCR fingerprinting. The isolates were identified as Lactococcus spp. (24 isolates: 21 L. lactis subsp. lactis, and 3 L. lactis) and Enterococcus spp. (33 isolates: $17 \mathrm{E}$. durans, 8 E. faecalis, 7 E. faecium, and 1 E. hirae). For Lactococcus spp., it was observed that sequencing of the V1 region (90 bp) of the $16 \mathrm{~S}$ rRNA gene was sufficient to provide a proper and reliable identification of the isolates, with variations that allowed differentiation of their species and subspecies [29]. However, sequencing of the same region in Enterococcus spp. isolates was not enough to provide a reliable identification at the species level, as observed in previous studies [45-48]; this limitation demanded sequencing of the pheS gene for a proper identification [30]. Considering the obtained results, isolates from raw goat milk that presented antimicrobial activity were identified as Lactococcus spp. and Enterococcus spp., as is usually observed in studies that investigate this activity in autochthonous microbiota from food systems $[9,11,49]$.

For rep-PCR fingerprinting analysis, the isolates were grouped considering their genus identification and $80 \%$ similarity to the obtained profiles (Figures 1 and 2). Lactococcus spp. isolates were grouped in four clusters, being 20 strains comprising in only one cluster, demonstrating large homology between them (Figure 1). For Enterococcus, the isolates were grouped in 11 clusters, demonstrating their biodiversity and evident similarities between isolates from the same species (Figure 2). Rep-PCR has already been described as a reliable methodology to determine the intra-species biodiversity of LAB isolated from foods, and also to assess the genetic variability of bacteriocinogenic strains $[9,50,51]$.

\section{Bacteriocin encoding genes}

Figures 1 and 2 also present the results for bacteriocin encoding genes assessed in the Lactococcus spp. and Enterococcus spp. isolates, respectively.

All Lactococcus spp. isolates presented lantibiotic genes in distinct associations, only one (GLc02) presenting $\operatorname{lan} \mathrm{B}, \operatorname{lan} \mathrm{C}$ and $\operatorname{lan} \mathrm{M}$ simultaneously (Figure 1). $\operatorname{lan} \mathrm{B}$ was the less frequent gene, while $\operatorname{lanC}$ and lanM usually were present simultaneously in the majority of isolates; this result was expected, since both genes are located in the same operon in the bacterial genome [52]. However, the isolated presence of $\operatorname{lan} \mathrm{C}$ or $\operatorname{lan} \mathrm{M}$ has already been described in previous studies $[19,25]$. For Enterococcus isolates, 30 isolates presented at least one of the tested lantibiotic genes; no isolates presented $\operatorname{lan} \mathrm{B}, \operatorname{lan} \mathrm{C}$ and lanM simultaneously (Figure 2). Cytolisin is a class I lantibiotic produced by Enterococcus spp., a bacteriocin that can be related to the tested genes [53]. Considering the antimicrobial potential of the isolates, the presence of at least one of the tested genes would be sufficient for lantibiotic production $[17,19]$.

A lower frequency of positive results was observed for nis in the tested Lactococcus isolates (9 strains) compared to similar studies identifying the bacteriocinogenic potential of this genus (Figure 1) [9,22,25,49]. Still considering the results for the nis gene, ten Enterococcus isolates presented typical PCR amplification products (Figure 2). The occurrence of Enterococcus strains
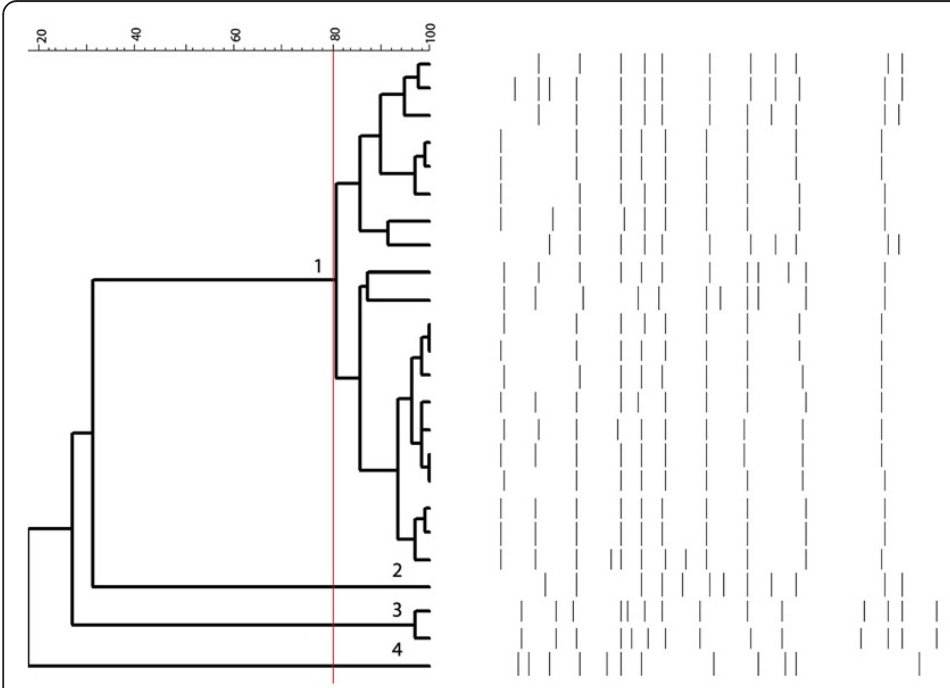

\begin{tabular}{|c|c|}
\hline Codes & Identification \\
\hline GLc19 & $\begin{array}{l}\text { Lac toc } \propto c \text { us lac tis subsp. lect is } \\
\text { Lat toc } \propto c \text { us lact is subsp. lact is }\end{array}$ \\
\hline GLc18 & Lac toc $\propto c$ us lac tis subsp. lact is \\
\hline GLc16 & La toc cocus lactis subsp. lact is \\
\hline GLc17 & Lac toc $\propto c$ us lactis subsp. lactis \\
\hline GLc15 & Lac toc œce us lac tis subsp. lact is \\
\hline GLc14 & Lac toc $\propto c$ us lactis subsp. lact is \\
\hline GLc22 & Lac toc $\propto c$ us lac tis subsp. lact is \\
\hline GLc02 & Lac toc 0 c us lactis \\
\hline GLc03 & Lac tococcus lactis \\
\hline GLc11 & Lac toc œc us lac tis subsp. lact is \\
\hline GLc12 & Lactocœc us lactis subsp. lactis \\
\hline GLc10 & Lac toc $\propto c$ cus lac tis subsp. lact is \\
\hline GLc06 & Lac toc œc us lac tis subsp. lact is \\
\hline GLc07 & Lac toc $\propto c$ us lac tis subsp. lact is \\
\hline GLc08 & La toc $\propto c$ cus lac tis subsp. lact is \\
\hline GLc09 & Lactocœc us lactis subsp. lactis \\
\hline GLc04 & Lac tococcus lac tis subsp. lact is \\
\hline GLc05 & Lac toc $\propto 0 c$ us lac tis subsp. lact is \\
\hline GLc01 & Lac toc oc us lactis \\
\hline GLc24 & Lac toc œc us lac tis subsp. lact is \\
\hline GLc20 & Lac toc œc us lactis subsp. lact is \\
\hline GLc21 & Lac toc $\propto c$ cus lac tis subsp. lact is \\
\hline GLc & Lac toc $\propto c$ us lactis subsp. lact is \\
\hline
\end{tabular}

$\begin{array}{cccc}\text { lanB } & \text { lanC } & \text { lanM } & \text { nis } \\ - & + & + & + \\ - & + & + & - \\ - & + & + & + \\ - & + & + & - \\ - & + & + & - \\ - & - & + & - \\ - & + & + & + \\ - & + & + & - \\ + & + & + & - \\ - & - & + & + \\ - & + & + & - \\ - & + & + & - \\ - & + & + & - \\ - & + & + & - \\ - & + & + & - \\ - & + & + & + \\ - & + & + & - \\ - & + & + & + \\ - & + & + & + \\ - & + & + & - \\ - & + & - & - \\ - & - & + & + \\ - & - & + & + \\ - & + & + & -\end{array}$

Figure 1 Dendogram generated after cluster analysis of rep-PCR fingerprints of bacteriocinogenic Lactococcus spp. obtained from raw goat milk. Clusters are indicated by numbers. Presence (+) or absence (-) of bacteriocin encoding genes are also indicated. 


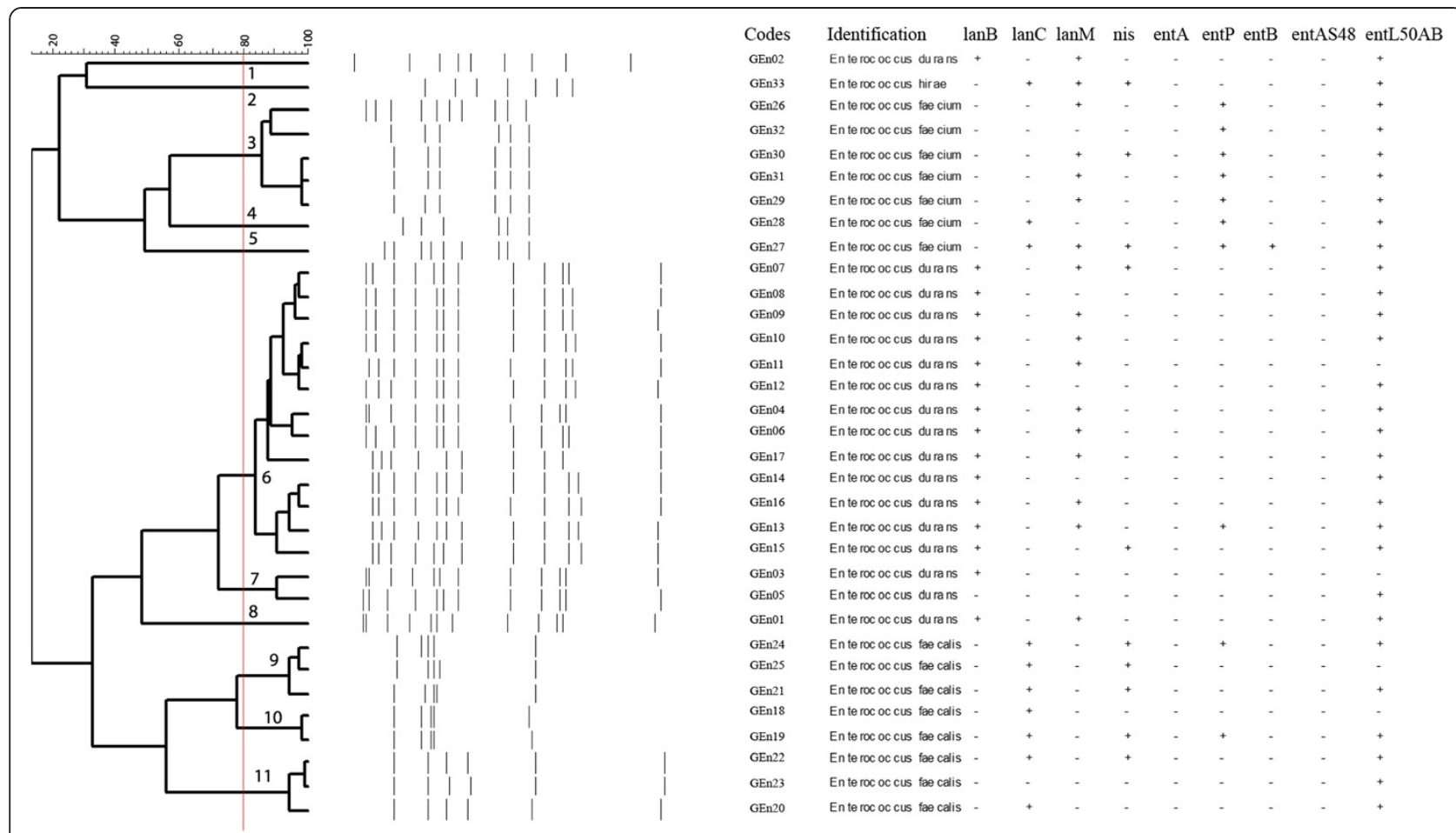

Figure 2 Dendogram generated after cluster analysis of rep-PCR fingerprints of bacteriocinogenic Enterococcus spp. obtained from raw goat milk. Clusters are indicated by numbers. Presence $(+)$ or absence $(-)$ of bacteriocin encoding genes are also indicated.

possessing nisin-related genes has already been reported, and can be explained by the capability of this genus to acquire new genetic elements [40]. However, positive results for the nis gene must not be related to the production of nisin by Enterococcus isolates.

No Enterococcus isolates presenting encoded genes for enterocin A and enterocin AS-48 (Figure 2). Only a single isolate (GEn27) presented a positive result for the enterocin $\mathrm{B}$ gene, and 10 isolates, from five distinct clusters, for the enterocin P gene (Figure 2). Enterocin A and enterocin $\mathrm{P}$ are bacteriocins classified in subclass IIa (pediocin-like bacteriocins), with typical high inhibitory activity against Listeria spp. [53]. The enterocin L50AB gene was detected in 29 isolates, from all identified genetic profiles (Figure 2); this bacterocin is classified in subclass IIb, characterized by its synthesis without leader peptides and demanding a complex system for transport [54,55].

The three LAB isolates that presented antimicrobial activity but an absence of enzymatic sensitivity in their produced substances (Table 2) were two Lactococcus (GLc20 and GLc21) and one Enterococcus (GEn27) (Figures 1 and 2). However, the three isolates presented positive results for bacteriocin-related genes, indicating that they were unable to express them. When assessing the bacteriocingeonic potential and activity of LAB, the absence of production of bacteriocins by gene positive strains is a common finding, since bacteriocin production is mediated by a diversity of genetic and environmental factors $[13,40]$.

\section{Nisin gene sequencing and inhibitory spectrum of nisin positive isolates}

The nine Lactocccus isolates that presented positive results for nis were identified as capable of producing a novel nisin variant. Their amino-acid sequence were diverse from to the other nisin variants already described (Figure 3). In all translated sequences the typical variation in nisin $\mathrm{Z}$ was identified: an asparagine instead of a histidine in position 27 (Figure 3), as described previously $[25,56]$. In addition, all isolates presented identical variations in their translated sequences when compared to a reference sequences of nisin (Figure 3): 1) in the leader peptide, an aspartic acid was replaced by an asparagine in position -7; 2) except for GLc03, an isoleucine was replaced by a valine in position +4 ; and 3 ) a leucine was replaced by a valine in position +16 (Figure 3 ). Concerning the nisin leader peptide sequence, in the position -7 , one negative-charged amino-acid (aspartic acid) was replaced by one uncharged amino-acid (asparagine). This same replacement also occurs in Nisin U1 (Figure 3). Indicating that this change cannot interfere with the correct activity of the peptide. It is important to highlight two characteristics: 1) variations in 


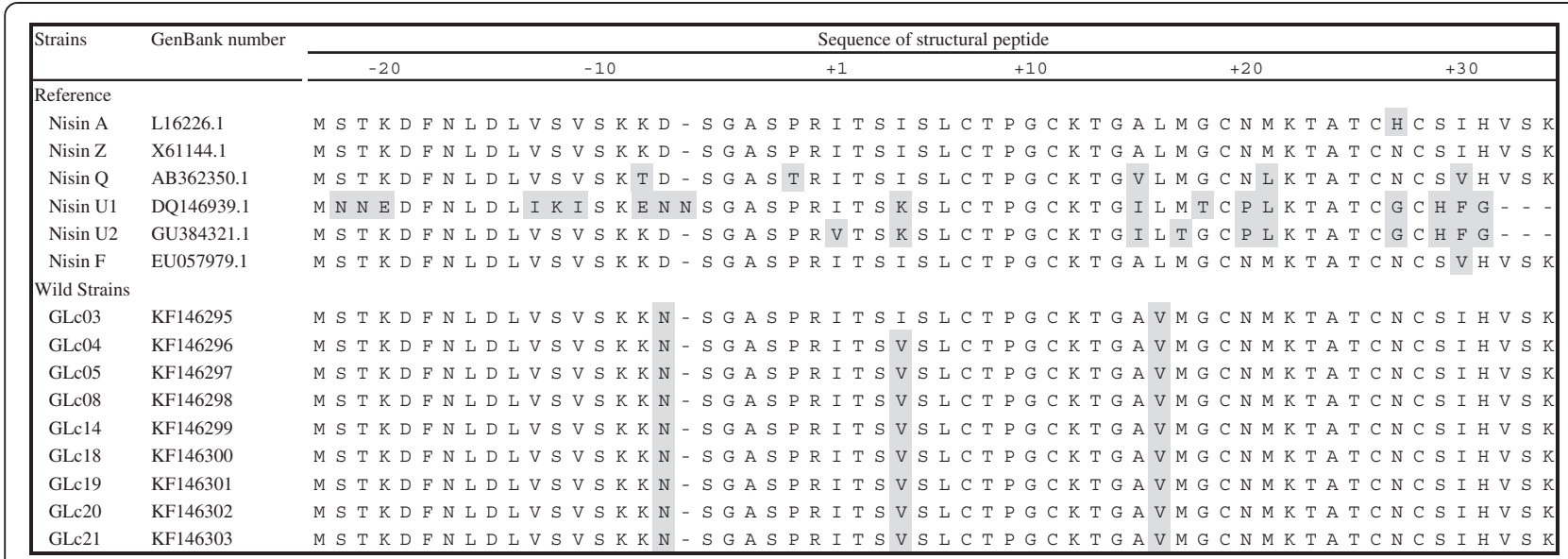

Figure 3 Amino-acid sequences of a novel nisin variants deduced by the sequencing of nisin region from nine Lactococcus spp. strains obtained from raw goat milk and compared to the sequences of nisin $A, Z, Q, F$ and $U$. The leader peptide is composed by 23 amino-acids, followed by amino-acids representing the mature peptide. Amino-acids highlighted in grey indicate variations when compared to the nisin A (the first nisin variation to be discovered) references. The complete amino-acid sequencesfrom the 9 wild strains have been deposited in GenBank (accession numbers KF146295 to KF146303, respectively).

Table 3 Inhibitory activity (diameters of inhibition halos, $\mathrm{mm}$ ) of nis positive Lactococcus isolates obtained from raw goat milk against target microorganisms, identified by the spot-on-the-lawn methodology

\begin{tabular}{|c|c|c|c|c|c|c|c|c|c|c|c|}
\hline \multirow[t]{2}{*}{ Target genus } & \multirow[t]{2}{*}{ Species/serotype } & \multirow[t]{2}{*}{ Origin* } & \multicolumn{9}{|c|}{ nis positive isolates } \\
\hline & & & GLc04 & GLc05 & GLc08 & GLc14 & GLc18 & GLc19 & GLC20 & GLc21 & GLc03 \\
\hline Lactobacillus & L. sakei & ATCC 15521 & 11 & 13 & 9 & 9 & 5 & 11 & 0 & 0 & 5 \\
\hline \multirow[t]{3}{*}{ Lactococcus } & L. lactis subsp. lactis & ATCC 7962 & 11 & 9 & 8 & 7 & 0 & 7 & 0 & 0 & 0 \\
\hline & L. lactis subsp. lactis & GLC18, wild strain, present study & 13 & 11 & 11 & 11 & 0 & 12 & 0 & 0 & 7 \\
\hline & L. lactis subsp. lactis & GLc22, wild strain, present study & 13 & 11 & 11 & 7 & 7 & 10 & 7 & 7 & 7 \\
\hline \multirow[t]{4}{*}{ Listeria } & L. monocytogenes & ATCC 7644 & 11 & 11 & 11 & 9 & 15 & 13 & 7 & 7 & 9 \\
\hline & L. monocytogenes & ATCC 15313 & 9 & 9 & 7 & 7 & 0 & 7 & 7 & 5 & 10 \\
\hline & L. monocytogenes & 60 , wild strain, beef origin & 15 & 14 & 12 & 9 & 7 & 13 & 5 & 5 & 5 \\
\hline & L. inoccua & 76 , wild strain, beef origin & 5 & 5 & 5 & 5 & 5 & 5 & 5 & 5 & 9 \\
\hline \multirow[t]{6}{*}{ Staphylococcus } & S. aureus & ATCC 12598 & 9 & 7 & 7 & 7 & 7 & 5 & 7 & 7 & 7 \\
\hline & S. aureus & ATCC 14458 & 9 & 7 & 7 & 7 & 7 & 9 & 11 & 7 & 7 \\
\hline & S. aureus & ATCC 29213 & 8 & 7 & 7 & 7 & 7 & 7 & 9 & 0 & 7 \\
\hline & S. aureus & 27AF1, wild strain, cheese origin & 9 & 9 & 9 & 7 & 5 & 11 & 7 & 0 & 9 \\
\hline & S. aureus & 27ST1, wild strain, cheese origin & 9 & 9 & 9 & 7 & 5 & 7 & 11 & 7 & 9 \\
\hline & S. aureus & 26BP6, wild strain, cheese origin & 13 & 13 & 14 & 7 & 7 & 13 & 7 & 0 & 7 \\
\hline \multirow[t]{2}{*}{ Escherichia } & E. coli & ATCC 11229 & 0 & 0 & 0 & 0 & 0 & 0 & 0 & 0 & 0 \\
\hline & E. coli & ATCC 00171 & 0 & 0 & 0 & 0 & 0 & 0 & 0 & 0 & 0 \\
\hline \multirow[t]{2}{*}{ Pseudomonas } & P. aeruginosa & ATCC 27853 & 5 & 5 & 5 & 5 & 0 & 0 & 5 & 0 & 0 \\
\hline & P. fluorescens & ATCC 10038 & 5 & 5 & 5 & 0 & 0 & 0 & 0 & 0 & 0 \\
\hline \multirow[t]{4}{*}{ Salmonella } & S. Typhimurium & ATCC 14028 & 7 & 7 & 5 & 5 & 0 & 0 & 0 & 0 & 0 \\
\hline & S. Cholerasuis & 38 , wild strain, beef origin & 0 & 0 & 0 & 0 & 0 & 0 & 0 & 0 & 0 \\
\hline & S. Enteritidis & 258 , wild strain, poultry origin & 7 & 7 & 7 & 5 & 5 & 5 & 5 & 5 & 0 \\
\hline & S. Typhi & 40, wild strain, beef origin & 0 & 0 & 0 & 0 & 0 & 0 & 0 & 0 & 0 \\
\hline
\end{tabular}

*ATCC: American Type Culture Collection, Manassas, VA. 
the sequence between positions -18 and -15 would interfere with nisin production, and 2) mutagenesis in $\mathrm{Arg}^{1-}$ and $\mathrm{Ala}^{4-}$ would affect cleavage of the leader peptide, resulting in a non-active nisin [52]. However, the observed modification in the leader peptide of the translated sequences was not in these regions, indicating that nisin production and activity would not be affected in the tested isolates (Figure 3). Considering the mature peptide, in positions +4 and +16 of the nisin sequence, one neutral amino-acid (isoleucine and leucine respectively) was replaced by other neutral amino-acid (valina). The only described modification in the +4 region is in nisin U (isoleucine replaced by lysine) [19]. The last variation and well know is in position +27 , where one uncharged amino-acid (asparagine) is replaced by one positive electrically charge and basic amino-acid (histidin). This typical change for nisin $\mathrm{Z}$ was previously described as responsible for increasing its inhibitory spectrum due to its better diffusion capacity in culture media. It is common to observe variations in the amino-acid sequences of lantibiotics, including nisin, that then require proper characterization since they can interfere with the antimicrobial activity of these substances [18]. The observed variations in the translated nisin sequences have not been reported before, after consulting GenBank.

Table 3 shows the inhibitory activity of the nis positive Lactococcus isolates against several microbial targets. It can be observed that the isolates presented inhibitory activity mainly against the tested Gram positive bacteria, and lower frequencies of inhibition against Gram negative bacteria. These results indicate that the bacteriocins produced by the tested LAB isolates have interesting antimicrobial activities, highlighting the relevance of raw goat milk as a source of bacteriocinogenic strains [23]. In addition, the obtained results indicate that the variations in nisin structure predicted in the present study (Figure 3) did not affect the antimicrobial activity of the isolates. Considering the main characteristics of bacteriocins, the inhibitory activity against the tested Gram negative bacteria must be due to non-specific antimicrobial substances produced by the LAB strains, such as organic acids or peroxide [24,34].

\section{Conclusions}

In conclusion, the present study highlighted the diversity of LAB in the raw goat milk microbiota, representing a potential source of novel bacteriocinogenic strains to be further studied concerning their antimicrobial activity. In addition, Lactococcus strains were identified as possessing variations in their nis gene sequences that would result in production of a nisin variant not yet described, and also possessing a wide inhibitory spectrum.

\section{Availability of supporting data}

The amino-acid and nucleotide sequences for nisin gene from positive Lactococcus spp. strains were deposited and available in the GenBank (National Center for Biotechnology Information, http://www.ncbi.nlm.nih.gov/genbank). The accession numbers are KF146295 - KF146303.

\section{Competing interests}

The authors declare that they have no competing interests.

\section{Authors' contributions}

LMP: AB, MT, ES, FG. LAN: AB, MT, ES, FG. Both authors read and approved the final manuscript.

\section{Acknowledgements}

The authors are thankful to CNPq, CAPES, and FAPEMIG.

Received: 12 April 2013 Accepted: 6 February 2014

Published: 12 February 2014

\section{References}

1. Food and Agriculture Organization of the United Nations. http://faostat3. fao.org/faostat-gateway/go/to/download/Q/QI/E

2. Haenlein G: Goat milk in human nutrition. Small Ruminant Res 2004, 51(2):155-163

3. Asteri I, Kittaki N, Tsakalidou E: The effect of wild lactic acid bacteria on the production of goat's milk soft cheese. Int J Dairy Technol 2010, 63(2):234-242

4. Psoni L, Kotzamanidis C, Yiangou M, Tzanetakis N, Litopoulou-Tzanetaki E: Genotypic and phenotypic diversity of Lactococcus lactis isolates from Batzos, a Greek PDO raw goat milk cheese. Int J Food Microbiol 2007, 114(2):211-220.

5. Colombo E, Franzetti L, Frusca M, Scarpellini M: Phenotypic and genotypic characterization of lactic acid bacteria isolated from artisanal italian goat cheese. J Food Prot 2010, 73(4):657-662.

6. Nikolic M, Terzic-Vidojevic A, Jovcic B, Begovic J, Golic N, Topisirovic L. Characterization of lactic acid bacteria isolated from Bukuljac, a homemade goat's milk cheese. Int J Food Microbiol 2008, 122(1):162-170.

7. Perin L, Miranda R, Camargo A, Colombo M, Carvalho A, Nero L: Antimicrobial activity of the Nisin Z producer Lactococcus lactis subsp. lactis Lc08 against Listeria monocytogenes in skim milk. Arq Bras Med Vet Zootec 2013, 65(5):1554-1560.

8. Pingitore EV, Todorov SD, Sesma F, Franco BDGM: Application of bacteriocinogenic Enterococcus mundtii CRL35 and Enterococcus faecium ST88Ch in the control of Listeria monocytogenes in fresh Minas cheese. Food Microbiol 2012, 32(1):38-47.

9. Dal Bello B, Rantsiou K, Bellio A, Zeppa G, Ambrosoli R, Civera T, Cocolin L: Microbial ecology of artisanal products from North West of Italy and antimicrobial activity of the autochthonous populations. LWT - Food Sci Technol 2010, 43(7):1151-1159.

10. Nero LA, Mattos MR, Barros MAF, Ortolani MBT, Beloti V, Franco BDGM: Listeria monocytogenes and Salmonella spp. in raw milk produced in Brazil: occurrence and interference of indigenous microbiota in their isolation and development. Zoonoses Public Health 2008, 55(6):299-305.

11. Ortolani MBT, Moraes PM, Perin LM, Viçosa GN, Carvalho KG, Silva A Jr, Sesma F, Franco BDGM, Nero LA: Molecular identification of naturally occurring bacteriocinogenic and bacteriocinogenic-like lactic acid bacteria in raw milk and soft cheese. J Dairy Sci 2010, 93(7):2880-2886.

12. Munoz-Atienza E, Gomez-Sala B, Araujo C, Campanero C, del Campo R, Hernandez P, Herranz C, Cintas L: Antimicrobial activity, antibiotic susceptibility and virulence factors of Lactic Acid Bacteria of aquatic origin intended for use as probiotics in aquaculture. BMC Microbio/ 2013, 13(1):15.

13. Cotter PD, Hill C, Ross PR: Bacteriocins: developing innate immunity for food. Nat Rev Microbio/ 2005, 3(10):777-788.

14. Leroy F, De Vuyst L: Lactic acid bacteria as functional starter cultures for the food fermentation industry. Trends Food Sci Technol 2004, 15(2):67-78.

15. Castellano P, Belfiore C, Fadda S, Vignolo G: A review of bacteriocinogenic lactic acid bacteria used as bioprotective cultures in fresh meat produced in Argentina. Meat Sci 2008, 79(3):483-499. 
16. De Vuyst L, Leroy F: Bacteriocins from lactic acid bacteria: production, purification, and food applications. J Mol Microbiol Biotechnol 2007, 13(4):194-199.

17. Hyink O, Balakrishnan M, Tagg JR: Streptococcus rattus strain BHT produces both a class I two-component lantibiotic and a class II bacteriocin. FEMS Microbiol Lett 2006, 252(2):235-241.

18. McAuliffe O, Ross RP, Hill C: Lantibiotics: structure, biosynthesis and mode of action. FEMS Microbiol Rev 2001, 25(3):285-308.

19. Wirawan RE, Klesse NA, Jack RW, Tagg JR: Molecular and genetic characterization of a novel nisin variant produced by Streptococcus uberis. Appl Environ Microbiol 2006, 72(2):1148-1156.

20. Franciosi E, Settanni L, Cavazza A, Poznanski E: Biodiversity and technological potential of wild lactic acid bacteria from raw cows' milk. Int Dairy J 2009, 19(1):3-11.

21. Ortolani MBT, Yamazi AK, Moraes PM, Viçosa GN, Nero LA: Microbiological quality and safety of raw milk and soft cheese and detection of autochthonous lactic acid bacteria with antagonistic activity against Listeria monocytogenes, Salmonella spp., and Staphylococcus aureus. Foodborne Pathog Dis 2010, 7(2):175-180.

22. Rodríguez E, González B, Gaya P, Nuñez M, Medina M: Diversity of bacteriocins produced by lactic acid bacteria isolated from raw milk. Int Dairy J 2000, 10(1):7-15.

23. Schirru S, Todorov SD, Favaro L, Mangia NP, Basaglia M, Casella S, Comunian R, Franco BDGM, Deiana P: Sardinian goat's milk as source of bacteriocinogenic potential protective cultures. Food Control 2012, 25(1):309-320

24. Deegan LH, Cotter PD, Hill C, Ross P: Bacteriocins: Biological tools for bio-preservation and shelf-life extension. Int Dairy J 2006, 16(9):1058-1071.

25. Perin LM, Moraes PM, Viçosa GN, Silva Júnior A, Nero LA: Identification of bacteriocinogenic Lactococcus isolates from raw milk and cheese capable of producing nisin A and nisin Z. Int Dairy J 2012, 25(1):46-51.

26. Kruger MF, Barbosa MS, Miranda A, Landgraf M, Destro MT, Todorov SD, Franco BDGM: Isolation of bacteriocinogenic strain of Lactococcus lactis subsp. lactis from Rocket salad (Eruca sativa Mill.) and evidences of production of a variant of nisin with modification in the leader-peptide. Food Control 2013, 33(2):467-476.

27. Lewus CB, Kaiser A, Montville TJ: Inhibition of food-borne bacterial pathogens by bacteriocins from lactic acid bacteria isolated from meat. Appl Environ Microbiol 1991, 57(6):1683-1688.

28. Tagg JR, Dajani AS, Wannamaker LW: Bacteriocins of gram-positive bacteria. Bacteriol Rev 1976, 40(3):722

29. Klijn N, Weerkamp AH, de Vos WM: Identification of mesophilic lactic acid bacteria by using polymerase chain reaction-amplified variable regions of 16S rRNA and specific DNA probes. Appl Environ Microbiol 1991, 57(11):3390-3393.

30. Naser SM, Thompson FL, Hoste B, Gevers D, Dawyndt P, Vancanneyt M, Swings J: Application of multilocus sequence analysis (MLSA) for rapid identification of Enterococcus species based on rpoA and pheS genes. Microbiology 2005, 151(7):2141-2150.

31. Li H, O'Sullivan DJ: Heterologous expression of the Lactococcus lactis bacteriocin, nisin, in a dairy Enterococcus strain. Appl Environ Microbiol 2002, 68(7):3392-3400.

32. Toit MD, Franz CMAP, Dicks LMT, Holzapfel WH: Preliminary characterization of bacteriocins produced by Enterococcus faecium and Enterococcus faecalis isolated from pig faeces. J Appl Microbiol 2001, 88(3):482-494

33. Wouters J, Ayad EHE, Hugenholtz J, Smit G: Microbes from raw milk for fermented dairy products. Int Dairy J 2002, 12(2):91-109.

34. Carr FJ, Chill D, Maida N: The lactic acid bacteria: a literature survey. Crit Rev Microbiol 2002, 28(4):281-370.

35. Delavenne E, Mounier J, Déniel F, Barbier G, Le Blay G: Biodiversity of antifungal lactic acid bacteria isolated from raw milk samples from cow, ewe and goat over one-year period. Int J Food Microbiol 2012, 155(3):185-190.

36. Medina RB, Oliszewski R, Abeijón Mukdsi MC, Van Nieuwenhove CP, González SN: Sheep and goat's dairy products from South America: Microbiota and its metabolic activity. Small Ruminant Res 2011, 101(1-3):84-91.

37. Scintu MF, Piredda G: Typicity and biodiversity of goat and sheep milk products. Small Ruminant Res 2007, 68(1):221-231.
38. Moraes PM, Perin LM, Tassinari Ortolani MB, Yamazi AK, Viçosa GN, Nero LA: Protocols for the isolation and detection of lactic acid bacteria with bacteriocinogenic potential. LWT - Food Sci Technol 2010, 43(9):1320-1324.

39. Moraes PM, Perin LM, Todorov SD, Silva A Jr, Franco BDGM, Nero LA Bacteriocinogenic and virulence potential of Enterococcus isolates obtained from raw milk and cheese. J App/ Microbiol 2012, 113(2):318-328.

40. Riley MA, Wertz JE: Bacteriocins: evolution, ecology, and application. Annu Rev Microbiol 2002, 56(1):117-137.

41. Bromberg R, Moreno I, Delboni RR, Cintra HC, Oliveira PTV: Characteristics of the bacteriocin produced by Lactococcus lactis subsp. cremoris CTC 204 and the effect of this compound on the mesophilic bacteria associated with raw beef. World J Microbiol Biotechnol 2005, 21(3):351-358.

42. de Martinis ECP, Santarosa PR, Freitas FZ: Caracterização preliminar de bacteriocinas produzidas por seis cepas de bactérias láticas isoladas de produtos cárneos embalados a vácuo. Cien Tecnol Alim 2003, 23(2):195-199.

43. Lewus CB, Sun S, Montville TJ: Production of an amylase-sensitive bacteriocin by an atypical Leuconostoc paramesenteroides strain. Appl Environ Microbiol 1992, 58(1):143-149.

44. Todorov SD, Dicks LMT: Effect of modified MRS medium on production and purification of antimicrobial peptide ST4SA produced by Enterococcus mundtii. Anaerobe 2009, 15(3):65-73.

45. Campos CA, Rodríguez Ó, Calo-Mata P, Prado M, Barros-Velázquez J: Preliminary characterization of bacteriocins from Lactococcus lactis, Enterococcus faecium and Enterococcus mundtii strains isolated from turbot (Psetta maxima). Food Res Int 2006, 39(3):356-364.

46. Giraffa G, Neviani E: DNA-based, culture-independent strategies for evaluating microbial communities in food-associated ecosystems. Int J Food Microbiol 2001, 67(1):19-34.

47. Mohania D, Nagpal R, Kumar M, Bhardwaj A, Yadav M, Jain S, Marotta F, Singh V, Parkash O, Yadav H: Molecular approaches for identification and characterization of lactic acid bacteria. J Digest Dis 2008, 9(4):190-198.

48. Moraes PM, Perin LM, Silva A Jr, Nero LA: Comparison of phenotypic and molecular tests to identify lactic acid bacteria. Braz J Microbiol 2013, 44(1):109-112

49. Alegría Á, Delgado S, Roces C, López B, Mayo B: Bacteriocins produced by wild Lactococcus lactis strains isolated from traditional, starter-free cheeses made of raw milk. Int J Food Microbiol 2010, 143(1):61-66.

50. Gevers D, Huys G, Swings J: Applicability of rep-PCR fingerprinting for identification of Lactobacillus species. FEMS Microbiol Lett 2001, 205(1):31-36.

51. Mohammed M, Abd El-Aziz H, Omran N, Anwar S, Awad S, El-Soda M Rep-PCR characterization and biochemical selection of lactic acid bacteria isolated from the Delta area of Egypt. Int J Food Microbiol 2009, 128(3):417-423.

52. McAuliffe $O$, Ryan MP, Ross $P$, Hill C, Breeuwer $P$, Abee T: Lacticin 3147, a broad-spectrum bacteriocin which selectively dissipates the membrane potential. App/ Environ Microbiol 1998, 64(2):439-445.

53. Javed A, Masud T, UI Ain Q, Imran M, Maqsood S: Enterocins of Enterococcus faecium, emerging natural food preservatives. Ann Microbiol 2011, 61(4):699-708.

54. Cintas LM, Casaus P, Holo H, Hernandez PE, Nes IF, Håvarstein LS: Enterocins L50A and L50B, two novel bacteriocins from Enterococcus faecium L50, are related to staphylococcal hemolysins. J Bacterio/ 1998 , 180(8):1988-1994.

55. Franz CMAP, Van Belkum MJ, Holzapfel WH, Abriouel H, Galvez A: Diversity of enterococcal bacteriocins and their grouping in a new classification scheme. FEMS Microbiol Rev 2007, 31(3):293-310.

56. Mulders JWM, Boerrigter IJ, Rollema HS, Siezen RJ, de Vos WM: Identification and characterization of the lantibiotic nisin Z, a natural nisin variant. Eur J Biochem 1991, 201(3):581-584.

doi:10.1186/1471-2180-14-36

Cite this article as: Perin and Nero: Antagonistic lactic acid bacteria isolated from goat milk and identification of a novel nisin variant Lactococcus lactis. BMC Microbiology 2014 14:36. 